\title{
The Two Faces of the Hungarian Empire
}

\author{
Bálint Varga \\ Eötvös Loránd Research Network, Institute of History, Budapest, Hungary \\ Corresponding author: Bálint Varga, email: varga.balint@btk.mta.hu
}

\begin{abstract}
This article investigates the uses of the term "Hungarian Empire" during the long nineteenth century. It argues that the term "empire" emerged in the Hungarian political discourse in the Vormärz era and it was used to denote the imagined integrity of Hungary proper, Transylvania, Croatia, Slavonia, and eventually Dalmatia on the grounds of the historic rights of the Holy Crown of Hungary in the form of a composite nation-state. This usage of the term became ubiquitous after the Austro-Hungarian Compromise. A second meaning pertaining to imperialist foreign policy entered the dictionary of Hungarian political discourse in the late nineteenth century. Fed by the recently created memory of the medieval Hungarian great power, several pressure groups in fin-de-siècle Hungary lobbied for a Hungarian (informal) empire in Southeastern Europe and beyond. While several lobby groups were firmly embedded in the framework of the AustroHungarian monarchy, some of these visionaries imagined a Hungarian empire independent from the Habsburg structures. A short comparison with the Croatian and Czech political discourses illuminates that the first meaning of empire (composite nation-state) did not differ in substance from contemporary terminology in other Habsburg lands but the second meaning (imperialism) was indeed a unique phenomenon in the Habsburg monarchy.
\end{abstract}

Keywords: empire; composite state; state rights; imperialism; foreign policy

Whether the late Habsburg monarchy can be defined as an empire and, if so, what kind of empire it was, has been at the forefront of research in the past few years. Characteristic of this trend is Pieter Judson's recent article-the very title of which provocatively poses the question, "L'Autriche-Hongrie était-elle un empire?" While stating that "the majority of imperial theories did not apply to this state," Judson nevertheless leaves little doubt that the Habsburg monarchy can indeed be regarded an empire. ${ }^{1}$ His evaluation coincides with the ideas and vocabulary of the age he considers: during the long nineteenth century, no one in the Habsburg lands hesitated to call this polity an empire. ${ }^{2}$ Other scholars, however, are more cautious. Arno Strohmayer, for instance, advanced the argument that the early modern "Habsburg Monarchy was no full-fledged empire but evinced several imperial dimensions."

Instead of pondering whether the Habsburg monarchy counts as an empire or not, most scholars have rather searched for the distinctive qualities of empire in Habsburg history. Imperial

\footnotetext{
${ }^{1}$ Pieter M. Judson, “L’Autriche-Hongrie était-elle un empire?," Annales 68, no. 3 (2008): 563-96. The citation in full length: "Le présent article s'appuie sur des travaux récents portant sur les droits civils, les cultures citoyennes, les structures institutionnelles et les pratiques politiques apparues en Autriche-Hongrie après 1867, pour démontrer que la plupart des théories de l'empire ne s'appliquent pas à cet État" (p. 565).

${ }^{2}$ Hannes Leidinger, "War die Habsburgermonarchie ein Imperium? Aktuelle wissenschaftliche Betrachtungen und zeitgenössische Debatten von 1900 bis 1918," in Österreich-Ungarns imperiale Herausforderungen: Nationalismen und Rivalitäten im Habsburgerreich um 1900, ed. Bernhard Bachinger, Wolfram Dornik, and Stephan Lehnstaedt (Göttingen, 2020), 27-44.

${ }^{3}$ Arno Strohmeyer, "Die Habsburgermonarchie in der Frühen Neuzeit - ein Imperium? Ein Problemaufriss," in Imperien und Reiche in der Weltgeschichte: Epochenübergreifende und globalhistorische Vergleiche, ed. Michael Gehler and Robert Rollinger (Wiesbaden, 2014), 1049.

(C) The Author(s), 2021. Published by Cambridge University Press on behalf of the Center for Austrian Studies, University of Minnesota. This is an Open Access article, distributed under the terms of the Creative Commons Attribution licence (http://creativecommons.org/licenses/by/4.0/), which permits unrestricted re-use, distribution, and reproduction in any medium, provided the original work is properly cited.
} 
representations have been widely studied, ${ }^{4}$ similar to the thriving investigation of the imperial practices in the administration of the late Habsburg monarchy. ${ }^{5}$ Scholars now largely agree on the imperial nature of Habsburg rule over peripheries such as Galicia and Bukovina ${ }^{6}$ and the quasicolony Bosnia-Herzegovina, ${ }^{7}$ as well as on the imperialist and colonial character of various forms of Austrian engagements in Africa and Asia. ${ }^{8}$

This article slightly differs from this stream of research. Instead of identifying another aspect of imperial rule of the Habsburg monarchy, it asks how many empires existed within the late Austria-Hungary. It elaborates on the evolution of the term "Hungarian Empire" (magyar birodalom) to show how the Magyar nationalist elite constructed its own vision of empire. Studying the concept of a Hungarian empire is certainly not an entirely new field. In an important chapter on the imperialist dimensions of Hungarian foreign policy during the long nineteenth century up to World War II, Ignác Romsics focuses on Hungarian imperialism, ${ }^{9}$ and this article does not endeavor to significantly alter his findings regarding foreign policy. Romsics, however, bypasses the most ubiquitous meaning of the term "Hungarian Empire" as it pertained to domestic matters. This article also answers the recent call of Laurence Cole, who argues that "more research is still needed regarding how 'empire' resonated within Transleithanian political discourse (including how far the Magyar elite may have thought in terms of a 'Hungarian empire,' not a common Austro-Hungarian one)." 10

\section{A Foreign Concept}

Until the early nineteenth century, the term "empire" sounded alien to most Hungarian ears. Empire, or birodalom in Hungarian, was defined through the title of its monarch, hence only polities headed by an emperor-whether a Kaiser (as in the Holy Roman Empire), a tsar (in Russia), or a sultan (in the Ottoman Empire)-were seen as empires. Associating empire with an emperor prevailed throughout the nineteenth century. As late as 1893, the Great Pallas Encyclopedia equated empire with a polity headed by an emperor (in Hungarian császár, derived from the Latin "Caesar," similar to the German "Kaiser"). ${ }^{11}$ Hungary, however, had never been formally ruled by an emperor; its monarch bore the title of king, and Hungary was thus a kingdom. Empire, believed Hungarians before the Vormärz, was not their matter; according to Hungarian legal orthodoxy, empires were to be found per definitionem only abroad. As late as 1910, the conservative legal scholar and publicist Mihály Réz employed the term "empire" only as a synonym for Austria and condemned any form of imperialization of Hungary that he equated with the sacrifice of Hungarian law and constitution on the altar of a centralized Austria, despite the fact that the term "Hungarian Empire" already had several meanings at the time of writing. ${ }^{12}$

\footnotetext{
${ }^{4}$ Brigitte Mazohl and Karin Schneider, “Translatio imperii'? Reichsidee und Kaisermythos in der Habsburgermonarchie," in Was vom Alten Reiche blieb...: Deutungen, Institutionen und Bilder des frühneuzeitlichen Heiligen Römischen Reiches Deutscher Nation im 19. und 20. Jahrhundert, ed. Matthias Asche, Thomas Nicklas, and Matthias Stickler (Munich, 2011), 101-28; Daniel L. Unowsky, The Pomp and Politics of Patriotism: Imperial Celebrations in Habsburg Austria, 1848-1916 (West Lafayette, 2005).

${ }^{5}$ John Deak, Forging a Multinational State: State Making in Imperial Austria from the Enlightenment to the First World War (Stanford, 2015); Jana Osterkamp, “Cooperative Empires: Provincial Initiatives in Imperial Austria," Austrian History Yearbook 47 (2016): 128-46.

${ }^{6}$ Klemens Kaps, "Creating Differences for Integration: Enlightened Reforms and Civilizing Missions in the Eastern European Possessions of the Habsburg Monarchy (1750-1815)," in Enlightened Colonialism: Civilization Narratives and Imperial Politics in the Age of Reason, ed. Damien Tricoire (Cham, 2017), 133-55.

${ }^{7}$ Clemens Ruthner, Habsburgs "Dark Continent": Postkoloniale Lektüren zur österreichischen Literatur und Kultur im langen 19. Jahrhundert (Tübingen, 2018); Clemens Ruthner and Tamara Scheer, Bosnien-Herzegowina und Österreich-Ungarn, 18781918: Annäherungen an eine Kolonie (Tübingen, 2018).

${ }^{8}$ Walter Sauer, "Habsburg Colonial: Austria-Hungary's Role in European Overseas Expansion Reconsidered," Austrian Studies 20 (2012): 5-23.

${ }^{9}$ Ignác Romsics, “A magyar birodalmi gondolat," in Múltról a mának: Tanulmányok és esszék a magyar történelemröl (Budapest, 2004), 121-58.

${ }^{10}$ Laurence Cole, "Visions and Revisions of Empire: Reflections on a New History of the Habsburg Monarchy," Austrian History Yearbook 49 (2018): 271.

${ }^{11}$ Pallas nagy lexikona: Az összes ismeretek enciklopédiája (Budapest, 1893-1904), s.v. "birodalom,” 3:310.

${ }^{12}$ Mihály Réz, Magyarország és Ausztria közjogi viszonya (Budapest, 1910).
} 
Yet, imperial institutions did infringe on Hungary. The Habsburg monarchs, as emperors of the Holy Roman Empire, granted the title imperial duke (Fürst) to some of the wealthiest and most loyal Hungarian magnates, such as the Esterházy, Grassalkovich, and Batthyány clans, and the archbishop of Esztergom. This title added to the exclusivity of the highest echelon of the Hungarian aristocracy vis-à-vis the "ordinary" counts, margraves, and barons. ${ }^{13}$

The distance between empire and Hungary further evaporated in 1804 when Francis II, thus far the Kaiser of the Holy Roman Empire and king of Hungary, created the new title "emperor of Austria," indicating that he now ruled over a state called the Austrian Empire (Kaisertum Österreich). In two years, he abandoned his claims to the Holy Roman Empire, and it thus ceased to exist. Evaluating this step, Charles Ingrao remarks that "Nearly three centuries after its creation, the Danubian commonwealth finally rested under a single crown." ${ }^{14}$ (Yet, the existence of a single crown by no means meant that imperial institutions were created. The only empirewide institution remained, as before, the army.) Hungarian legal scholars and politicians, however, vigorously opposed the idea of a single imperial crown: while several Hungarian counties congratulated Francis on his new title, they made it clear that it did not apply to Hungary. The opposition proved successful enough to make Emperor-King Ferdinand rule in Hungary as Ferdinand V, demonstrating that he took over the heritage of the Hungarian kings, rather than as Ferdinand I, which would have indicated he ruled as emperor. $^{15}$

The dividing lines between empire and Hungary, however, were not so strict, and the dichotomy of a Viennese court longing for centralization and a Hungarian political elite aiming at preserving its home rule and the illusion of sovereignty is an oversimplification best avoided. Some Hungarians felt drawn to the idea that Hungary did constitute a part of the Austrian Empire. One such was Ferenc Lamberg (Franz Philipp von Lamberg), a Hungarian-born count who originated from an age-old Carinthian aristocratic family and whose father had been granted Hungarian nobility. Lamberg embarked on a successful military career, and his unconditional loyalty to the Austrian Empire saw Emperor Ferdinand appoint him interim military commander and palatine of revolutionary Hungary in September 1848. This appointment was widely seen as unlawful and cost him his life only a few days later when, approaching Pest, a mob lynched him. Well before this, in his One More Terra Incognita: Knowledge on the Non-Hungarian Lands of the Austrian Empire, Lamberg advocated the unity of the Austrian Empire by familiarizing Hungarians with the allegedly unknown other provinces under the scepter of the Habsburgs. This book, similar to other journalistic exercises of Lamberg, was written in Hungarian-a remarkable fact, given the well-known preference of the imperial aristocracy and high military officers for German; yet, by choosing Hungarian, Lamberg consciously addressed a Hungarian readership and could argue for his vision of empire. ${ }^{16}$ While Lamberg's social standing perhaps explains his motivation for seeing Hungary as part of the Austrian Empire, some other authors of humbler background also shared this idea. For instance, István Lassú, a diligent but unoriginal scholar, included Hungary in his Statistical, Geographic, and Historical Description of the Austrian Empire (1829), and some geography textbooks also claimed Hungary to be part of the Austrian Empire. ${ }^{17}$

\footnotetext{
${ }^{13}$ Géza Pálffy, “An 'Old Empire’ on the Periphery of the Old Empire: The Kingdom of Hungary and the Holy Roman Empire in the Sixteenth and Seventeenth Centuries," in The Holy Roman Empire, 1495-1806: A European Perspective, ed. R. J. W. Evans and Peter H. Wilson (Leiden, 2012), 275-76. In 1886, the title duke was introduced to Hungarian law, too.

${ }^{14}$ Charles Ingrao, The Habsburg Monarchy 1618-1815 (Cambridge, 1994), 229.

${ }^{15}$ Ernő Nagy, Az ausztriai császári cím fölvételéröl (Budapest, 1897), 29-32; R. J. W. Evans, "Communicating the Empire: The Habsburgs and Their Critics, 1700-1919," Transactions of the Royal Historical Society 19 (2009): 123-27. At the same time, the term House of Austria (Ausztriai Ház) was widely used as a synonym for the House of Habsburg.

${ }^{16}$ Ferencz Lamberg, Még egy Terra Incognita: Ismeretek s tudnivalók ausztriai birodalom nem-magyar tartományairól (Bratislava, 1841).

${ }^{17}$ István Lassú, Az austriai birodalomnak statistikai, geographiai, és históriai leírása (Buda, 1829); P. B. [Pál Bedeö], Általános földleírás, különös tekintettel az Austriai birodalomra, jelesen Magyar országra (Bratislava, 1843); Harmadik folyamat: Az Austriai Birodalomnak és Olaszországnak földrajza (Târgu Mureş, 1846). Avoiding the contested meaning of birodalom, the easiest way to describe all the provinces under the scepter of the Habsburg was the term "House of Austria" (Ausztriai ház).
} 


\section{Toward a Composite Nation-State: The Empire of the Crown of St. Stephen}

Yet, the voices claiming Hungary as part of the Austrian Empire remained rather marginal. Instead, during the Vormärz the term magyar birodalom entered the Hungarian political and academic vocabulary. In this second sense, birodalom meant an independent and composite monarchy, regardless of whether its monarch bore the title of emperor or king. This understanding of empire features in an 1879 lexicon that equated birodalom with the Latin regnum rather than imperium and defined it as "a larger polity led by a monarch, emperor or king, or that integrated several smaller states." 18 The Hungarian term birodalom thus reads "realm" rather than "empire" in English, similar to the two possible translations of the German Reich.

To understand what shape a Hungarian birodalom bore in the Vormärz, one needs to consider that the very definition of Hungary was in flux. Elek Fényes, a pioneering scholar of statistics and economics, proposed a quaternary definition of Hungarian territory. ${ }^{19}$ In the narrowest sense, claimed Fényes, Hungary proper covered only the territory under the direct control of the Hungarian civil authorities. The second definition added to this Croatia and Slavonia, justified by the fact that their estates, too, sent delegates to the Hungarian Diet (despite that Croatia had its own government and the two provinces shared a common Diet). The third definition expanded the notion of Hungary to Transylvania. At that moment, Transylvania maintained no legal ties to Hungary; nonetheless, in the Middle Ages it had been part of Hungary and only the Ottoman advance of the sixteenth century led to the division between Hungary and Transylvania. As Magyar nationalism advanced, it became a widely held idea that the disunity of Hungary and Transylvania was an unnatural phenomenon that had to amended-that is, the restoration of their unity was a sine qua non of the national revival. ${ }^{20}$ Finally, Fényes's broadest definition of Hungary included all the lands in Eastern and Southeast Europe that in the Middle Ages had stood for a time under Hungarian suzerainty: Dalmatia, Bosnia, Serbia, Bulgaria, Galicia, Wallachia, and Moldavia.

The ultimate justification for the inclusion of these lands, however, derived from a more abstract legal concept: the doctrine of the Holy Crown of St. Stephen. This doctrine stated that Hungary was a sovereign and indivisible polity divided into several lands (regna): Hungary proper, Transylvania, Slavonia, and Croatia (sometimes Dalmatia was also added to the list). All these lands declared their independence from any other province under the scepter of the Habsburgs, but from the 1790s, demonstrates László Péter, the Diet of Hungary proper "claimed the right to legislate for the other Lands (regna) under the Hungarian crown. And from the 1830s, the liberal nationalists called for all the Lands of the Hungarian crown to be united in a single governmental system." ${ }^{21}$ (Indeed, the Hungarian Diet demanded even the incorporation of Galicia into the Hungarian administration.) The term "Hungarian Empire" became coterminous with this effort and most often pertained to the second or third definition in the taxonomy of Fényes. It came to symbolize a call for the deeper integration of the scattered lands of the Crown of St. Stephen: the Hungarian Empire was nothing but a yetfragmented Hungarian nation-state in the parlance of romantic nation-builders. Several articles by Lajos Kossuth, then editor of the Pesti Hirlap, the central press of liberal nationalism in the 1840s, illustrates this meaning of empire: "Since one empire may have only one major administrative language, in the Hungarian empire this tongue shall be the Magyar." 22 "The single question is which living language shall be the administrative language of the sovereign Hungarian empire." 23 This magyar birodalom was believed to be a sovereign state, and thus located outside the Austrian Empire; and in contrast to the earlier understandings of empire, it was not derived from the title of its monarch but referred to its (temporary) composite nature. The imperialization of the Magyar romantic-nationalist discourse of the Vormärz merely disguised the attempt to create a homogeneous nation-state.

\footnotetext{
${ }^{18}$ Magyar lexikon, az összes tudományok enciklopédiája (Budapest, 1879-85), s.v. "birodalom."

${ }^{19}$ Elek Fényes, Magyarország statistikája (Pest, 1842), 2:111-12.

${ }^{20}$ Orsolya Völgyesi, "Erdély kérdése és a hazai nyilvánosság az 1830-as években," in Nemzet, faj, kultúra a hosszú 19. században Magyarországon és Európában, ed. Ferenc Hörcher, Mátyás Lajtai, and Béla Mester (Budapest, 2016), 178-91.

${ }^{21}$ László Péter, Hungary's Long Nineteenth Century: Constitutional and Democratic Traditions in a European Perspective: Collected Studies, ed. Miklós Lojkó (Leiden, 2012), 46-50, 56-58, citation at 56.

22"Viraszszunk," Pesti Hirlap, 19 June 1842. Emphasis added.

23“"Szabadka körlevele," Pesti Hirlap, 14 July 1842. Emphasis added.
} 
This discursive shift can be well traced by the publication history of Triple Little Mirror, an enormously popular elementary school textbook that went through some seventy editions between 1773 and 1868. The textbook was divided into three chapters (hence its title): the first provided a short overview of the Bible; the second discussed the geography, present conditions, and history of Hungary proper; while the third did the same of Transylvania. ${ }^{24}$ The subtitle of the original printing and that of the circa thirty subsequent editions referred to the history and geography of Hungary in the narrowest sense and Transylvania, indicating that they were separate entities nonetheless bound together by their shared past. From 1824 until circa 1843, the subtitle of most editions was changed to "Empire of Hungary and Transylvania," and henceforth the geography chapter was extended to Croatia, Slavonia, and the Military Frontier. A further innovation introduced the term Royal Hungarian Empire into the subtitle (1834); finally, in 1844, Transylvania was dropped from the subtitle, suggesting it was a genuine part of the Royal Hungarian Empire (nevertheless, the main corpus discussed it in a separate chapter). ${ }^{25}$ Fényes's work also followed a somewhat similar trajectory. His Current Statistics and Geography of Hungary and Her Adjacent Lands (1836-40) and Description of Hungary (1847) discussed Hungary according to the second definition. ${ }^{26}$ In 1848 , however, Fényes felt compelled to extend his scope to Transylvania: the first volume of his new but abridged work appeared under the title Statistics, Geography, and History of the Hungarian Empire. ${ }^{27}$

In 1848, Hungary's "lawful revolution" practically resulted in independence from the rest of the Habsburg monarchy and also forged a short-lived unification of Hungary proper and Transylvania. The making of the Hungarian Empire seemed to be on its way. The victory of the Austrian and Russian imperial armies in the war of 1849, however, dismantled the quasi-independence of Hungary and reintegrated it into the rejuvenated Austrian Empire. In a dynamic decade, all the lands under Habsburg rule were integrated into a centrally governed polity for the first (and last) time. Contemporaries adjusted to the realities: the term "empire" now referred exclusively to Austria and the notion of a Hungarian empire practically vanished from the discourse. Two new works by Fényes discussed Hungary in the narrowest sense and the entire Austrian Empire, respectively. ${ }^{28}$ A new edition of the Triple Little Mirror was turned into a secular geography and history textbook, the scope of which was extended to the entire Austrian Empire. ${ }^{29}$

The centralized Austrian Empire, despite all the monumental reforms it introduced, lasted only a decade. In 1860, a period of experimentation initiated the search for the best constitutional solution to settle the diverging interests of the many political groups present in the Habsburg lands. After the censored public sphere of the 1850s, a flood of op-eds and pamphlets outlined the most diverse scenarios for the future. ${ }^{30}$ In this context, the use of "Hungarian Empire" as an umbrella term for all the lands of the Crown of St. Stephen reemerged and, as earlier, represented the desire of their deeper integration. As early as 1861, the polymath Ferenc Toldy published The Constitutional Laws of the Hungarian Empire, a collection of historic laws, deliberately including legal sources that indicated the unity of Hungary proper, Croatia, Slavonia, and Transylvania-a Hungary according to the third category of the taxonomy of Fényes. ${ }^{31}$

In 1867, the Ausgleich put the Habsburg lands on a new footing. In the official discourse and legal texts, the term Reich was increasingly equated with Cisleithania: the Reichsrat and Reichsgericht, for instance,

\footnotetext{
${ }^{24}$ István Losontzi, Hármas kis tükör, melly I. a Szent Históriát, II. Magyar Országot, III. Erdély Országot, annak földével, polgári állapatjával, és históriájával, gyenge elmékhez alkalmaztatott módon, a nemes tanúlóknak, summásan, de világosan elöadja és kimutatja (Bratislava, 1773).

${ }^{25}$ László L. Lajtai, "Magyar nemzet vagyok": Az első magyar nyelvü és hazai tárgyú történelemkönyvek nemzetdiskurzusa (Budapest, 2013), 270-71; see the bibliography of the various titles at 530-40.

${ }^{26}$ Elek Fényes, Magyarországnak s a hozzá kapcsolt tartományoknak mostani állapotja statistikai és geographiai tekintetben, 6 vols. (Pest, 1836); Elek Fényes, Magyarország leírása, 2 vols. (Pest, 1847).

${ }^{27}$ Elek Fényes, Komárom vármegye: A magyar birodalom statisticai, geographiai és történeti tekintetben 1 (Pest, 1848).

${ }^{28}$ Elek Fényes, Magyarország geographiai szótára, mellyben minden város, falu és puszta, betürendben körülményesen leiratik (Pest, 1851); Elek Fényes, Az Ausztriai birodalom statistikája és földrajzi leirása (Pest, 1857).

${ }^{29}$ Lajos Hőke, Kis tükör, az ausztriai birodalmat, különösen Magyarországot mutató (Buda, 1857).

${ }^{30}$ Ágnes Deák, “'Kiegyenlítési programm-kovácsaink,' 1861-1865,” Századok 139, no. 3 (2005): 695-732.

${ }^{31}$ Ferenc Toldy, A magyar birodalom alaptörvényei (Buda, 1861), IX-XI.
} 
became organs of the Cisleithanian state without extending their portfolio to Hungary; the three common ministries of Austria-Hungary also replaced the term Reichsministerium by k. u. k. Ministerium, though only with a significant delay after the Ausgleich. The first " $k$ " in the widely used adjective $\mathrm{k} . \mathrm{u}$. $\mathrm{k}$. meant kaiserlich or imperial, in contrast to the second " $k$," abbreviating the Hungarian königlich or royal. ${ }^{32}$

Yet, in royal Hungary, the term "Hungarian Empire" became a buzzword. The Ausgleich made the Vormärz vision of the Hungarian Empire materialize to a large extent: Transylvania united with Hungary proper and the Military Frontier was dissolved and replaced by Hungarian and Croatian civil administration. Back in the Vormärz, the term "Hungarian Empire" was used concerning Croatia, Slavonia, and Transylvania and, as it has been claimed in the preceding text, the very use of the term "empire" practically equated with a cry for their unity. Once Transylvania merged with Hungary, this discursive trope was no longer needed when discussing this region. The discursive deimperialization of the relation of Hungary and Transylvania mirrored the fact that in 1867 two legally equal regna within the Crown of St. Stephen were transformed into the center and the periphery of a centralized state.

Instead of Transylvania, the term "Hungarian Empire" in the post-Ausgleich era pertained to the Hungarian-Croatian relations. In a special subcompromise concluded in 1868, Croatia-Slavonia retained its autonomy, though the leverage of the Hungarian government in Croatian matters remained significant. As it had before 1848, the Croatian Diet sent representatives to the Hungarian, a Croatian ministry was set up in Budapest, and Croats became Hungarian citizens. In the Hungarian legal and political discourse, Croatia was seen as an autonomous part of the sovereign Hungarian state that, nonetheless, lacked the genuine qualities of statehood. In the post-1867 era, the term "Hungarian Empire" referred in most cases to this understanding of statehood. For instance, Pesti Napló, a leading liberal-conservative daily printed in Budapest, commented on the victory of the Croatian-Serbian coalition (an alliance of Yugoslavist parties with a definite anti-Hungarian agenda) at the 1908 Croatian elections that it was "a great disappointment for all advocates of the Hungarian imperial politics," ${ }^{33}$ that is, for everyone who shared the convention that no Croatian statehood existed outside the Hungarian. The term "Hungarian Empire" as an equivalent to Hungary and Croatia-Slavonia became ubiquitous in nonpolitical contexts, too. In works such as The Air Pressure in the Hungarian Empire or A Piscicultural Outline of the Hungarian Empire, "empire" thus only means that their authors relied on data from both Hungary proper and Croatia-Slavonia; similarly, the booklet Mineral Waters and Spas of the Hungarian Empire informed the potential visitors about spas both in Hungary proper and in Croatia-Slavonia. ${ }^{34}$ In a similar manner, the Hungarian Royal Statistical Office summed up the numbers representing Hungary and Croatia-Slavonia under the label "Hungarian Empire." 35

While the Hungarian Empire pertaining to Croatia-Slavonia could be easily justified by actual public law, the secondary extension of the expression to Dalmatia was a more complicated issue. Dalmatia stood under Habsburg rule between 1797 and 1805 and since 1814. Since 1861, it had its provincial assembly and government, sent representatives to the Imperial Parliament in Vienna, and stood under the imperial government's orbit-in short, it nurtured legal ties neither to Croatia nor to Hungary. In the Middle Ages, however, the Croatian kings had occasionally ruled over parts of Dalmatia and bore the title of king of Dalmatia; the Croatian banus kept including Dalmatia in the title of his office even after Dalmatia become Venetian territory in the early fifteenth century. Because in the late eleventh century Croatia and Hungary entered a union, the Hungarian monarchs bore the title of king of Dalmatia, too. For Hungarian legal scholars from the early modern period to the early twentieth century, the Dalmatian royal title unquestionably belonged to the Crown of

\footnotetext{
${ }^{32}$ Gerald Stourzh, "Der Dualismus 1867-1918: Zur staatsrechtlichen und völkerrechtlichen Problematik der Doppelmonarchie," in Die Habsburgermonarchie 1848-1918, ed. Adam Wandruszka and Peter Urbanitsch, vol. 7, Verfassung und Parlamentarismus (Vienna, 2000), 1192-94.

33“Kudarc Horvátországban," Pesti Napló, 29 Feb. 1908.

${ }^{34}$ Zsigmond Róna, A légnyomás a Magyar Birodalomban 1861-től 1890-ig (Budapest, 1897); György Vutskits, A Magyar Birodalom halrajzi vázlata (Keszthely, 1904); Samu Papp and Vilmos Hankó, A magyar birodalom ásványvizei és fürdőhelyei (Budapest, 1907).

${ }^{35}$ This practice was also used by other statistical authors, such as Sándor Konek, Magyar birodalom statistikai kézikönyve folytonos tekintettel Ausztriára (Budapest, 1875).
} 
St. Stephen, and they argued that the Habsburg rule over the province was justified by this. ${ }^{36}$ In 1802 , Francis I acknowledged the right of the Hungarian Crown to Dalmatia in an address to the Hungarian Diet. Referring to historical arguments and the address of Francis, several Vormärz Diets discussed and demanded the expansion of the Hungarian governmental system to Dalmatia. ${ }^{37}$ In 1843 , the prominent liberal Miklós Wesselényi also advocated the idea of transferring Dalmatia to Croatia to receive the blessings of the Hungarian constitution (as opposed to the Vormärz absolutism). ${ }^{38}$ From the 1860s, when a myriad of constitutional and political constellations seemed possible and the integration of the more significant Transylvania also seemed within grasp, the issue of Dalmatia was raised again. János Hunfalvy, the founder of Hungarian geography, included Dalmatia in his Description of the Natural Conditions of the Hungarian Empire (1863-65). ${ }^{39}$ The always adaptive Fényes followed suit, also covering Dalmatia in his 1867 work The Nationalities of the Hungarian Empire. ${ }^{40}$ Because the attachment of Dalmatia to Croatia was endorsed by the Hungarian, Croatian, and, to a certain extent, Dalmatian political elites, too, ${ }^{41}$ the Hungarian-Croatian compromise of 1868 stated that Dalmatia was part of their union: the law enacting the compromise was called the "Act on the Reconciliation of the Issues in Public Law between Hungary and Croatia-Slavonia-Dalmatia" and it prescribed the Hungarian government the demand of the actual transfer of the province from Austrian to Croatian rule. Accordingly, both the Hungarian and the Croatian coat of arms used during Dualism included Dalmatia. In the following decades, several authors included Dalmatia into their vision of a Hungarian empire, among them a handful of geography textbook authors. ${ }^{42}$ The loudest pundit of the "Hungarian Empire" discourse centered on the question of Dalmatia was Rezsö Havass, an insurance expert and geographer who authored countless popular geography books and articles. Havass promoted a maritime turn in Hungarian foreign trade and policy, and hence advocated the development of Rijeka/Fiume, Hungary's main Adriatic port, and the Hungarian merchant fleet, as well as the attachment of Dalmatia directly to the Hungarian Empire to "restore" historic rights and to provide a solid basis for the Adriatic presence of Hungary. ${ }^{43}$ Despite all these symbolic and discursive efforts, Dalmatia remained part of Cisleithania until 1918. Lacking a Magyar-speaking population, the peripheral and impoverished Dalmatia never stirred up sufficient emotions in Hungary to make the Hungarian government approach Austria for its transfer to Transleithania.

The term "Hungarian Empire" as a proxy for a united nation-state-to-be did not necessarily center on the legal bonds among the different regna. For several authors, the term simply meant a call to create a strong nation-state. Among them, the most significant was Gusztáv Beksics, one of the most remarkable ideologues of the governing Liberal Party. ${ }^{44}$ Beksics's slow embrace of the term "empire" is telling. In his early works published in the 1880s, he used it as a synonym for Kaisertum, hence in connection to other states only. ${ }^{45}$ In 1892 , however, he argued for reform in Hungarian legal-political

\footnotetext{
${ }^{36}$ As early as in the sixteenth century, legal scholar István Werbőczy defined Dalmatia as a regnum within the lands of the Crown of Hungary. Werbőczy's work had a lasting impact on Hungarian legal scholarship and political discourse well into the nineteenth century. Péter, Hungary's Long Nineteenth Century, 43.

${ }^{37}$ Tivadar Botka, Az 1843/1844 országgyülési idöszakból néhány ismeretlenebb közjogi tárgy és megrögzött balvélemény felvilágosítva (Bratislava, 1844), 29-47.

${ }^{38}$ Miklós Wesselényi, Szózat a magyar és a szláv nemzetiség ügyében (Leipzig, 1843), 236; also in German: Eine Stimme über die ungarische und slawische Nationalität (Leipzig, 1844), 166.

${ }^{39}$ János Hunfalvy, A magyar birodalom természeti viszonyainak leírása, 3 vols. (Pest, 1863).

${ }^{40}$ Elek Fényes, A Magyar Birodalom nemzetiségei és ezek száma vármegyék és járások szerint (Pest, 1867).

${ }^{41}$ Antoni Cetnarowicz, Die Nationalbewegung in Dalmatien im 19. Jahrhundert: Vom "Slawentum" zur modernen kroatischen und serbischen Nationalidee (Frankfurt, 2008).

${ }^{42}$ Péter Pál Maár, A magyar birodalom földleírása különös tekintettel természeti, kereskedelmi, közlekedési és ipari viszonyaira (Pest, 1870); Károly Ballagi and Pál Király, A magyar birodalom leírása különös tekintettel az 1876. XXXIII. törv.-cikkre (Budapest, 1877).

${ }^{43}$ Rezső Havass, Dalmáczia visszacsatolása a magyar birodalomhoz (Budapest, 1889); Rezső Havass, Magyar imperiálizmus (Budapest, 1902).

${ }^{44}$ The best intellectual biography of Beksics is still Zsuzsa L. Nagy, “A 'nemzeti állam’ eszméje Beksics Gusztávnál," Századok 97, no. 6 (1963): 1242-78. A more recent but rather brief treatment: Rolf Müller, ed., Beksics Gusztáv (Budapest, 2005), 7-39.

${ }^{45}$ Censor [Gusztáv Beksics], Társadalmunk és nemzeti hivatásunk (Budapest, 1884); Atticus [Gusztáv Beksics], Uj korszak és politikai programmja (Budapest, 1889).
} 
terminology and advocated the equivalent terms "Hungarian State," "Hungarian Empire," and "Hungarian Monarchy." In his works authored in the 1890s, such as in the concluding chapter of The History of the Hungarian Nation, a monumental and representative undertaking celebrating the millennium of Hungarian history, he used the term "Empire of St. Stephen" in the sense of a united nation-state. ${ }^{47}$ Finally, empire became a central concept of Beksics in his late pamphlet The Empire of King Mathias and the Future of Hungary (1905). ${ }^{48}$ Beksics identified the reign of Mathias Corvinus (r. 1458-90) as the peak of medieval Hungary and as a blueprint for his age. In Beksics's vision, Mathias's Hungary was governed by a strong and centralized administration, had a high population density, and its population spoke predominantly Magyar. These three factors combined made Hungary an empire, argued Beksics, whose inner strength empowered Mathias to pursue an extensive foreign policy that even had the potential to develop into a great power. The same qualities could have guaranteed the future of Hungary: a strong and centralized government and a high and culturally homogeneousthat is, monolingual-population. Even though Beksics was less interested in the expansive foreign policy of either Mathias or of the envisioned Hungary, he believed that a centralized, populous, and monolingual Hungarian nation-state would automatically assume leadership within the Habsburg monarchy and become "the natural leader of the peoples of the Balkans." 49

\section{The Dream of a Hungarian Great Power}

Beksics's vision of a Hungarian protectorate over the Balkans leads to the second major usage of the term "Hungarian Empire": the various means to gain Hungarian leverage outside the lands of the Crown of St. Stephen. These visions fall into two categories: the first pertained to the Habsburg lands, while the second was concerned with the creation of a genuine Hungarian imperialism in the Balkans and Ottoman Empire-and occasionally even beyond.

The application of the term "Hungarian Empire" to the entire Habsburg monarchy can be first documented during the experimental years of the 1860s. A young county official and later senior clerk in the Ministry of Finance, József Tabódy, and a journalist, Károly Szini, proposed the rejuvenation of the Habsburg Empire by moving its political center to Hungary, its largest and geographically central province, with Buda and Pest replacing Vienna as the seat of the imperial court and administration, and by changing the name of the reformed polity to "the Hungarian Empire." made this idea obsolete, but from the 1880s the transfer of the center of the Austro-Hungarian monarchy from the allegedly decaying Vienna to Budapest, capital of the young and dynamic Hungary, became a frequently discussed topic. Two advocates of this idea framed their proposal as "the Hungarian Empire." First, in 1881 the journalist-poet János Vajda argued in the pamphlet The Politics of the Hungarian Empire that the declining Germans should be divested of the leading role in the Habsburg monarchy in favor of the young and ambitious Hungarians (the "untrustworthy" Slavs, of course, did not deserve this duty). ${ }^{51}$ Second, an unknown author hiding behind the pseudonym "Mercator" came forward with an unusual proposal: in 1908, he advocated for a Hungarian-Slavic alliance against pan-Germanism-only a Hungarian empire, supported by its Slavic allies, he argued, could save the Habsburg monarchy from the insatiable German nationalism. ${ }^{52}$ In contrast to empire understood as the integration of the lands of the Crown of St. Stephen, the Hungarian Empire equivalent to the Hungarianization of the Habsburg monarchy stood neither against nor outside Austria but meant

\footnotetext{
${ }^{46}$ Gusztáv Beksics, A dualizmus története, közjogi értelme és nemzeti törekvéseink (Budapest, 1892), 270.

${ }^{47}$ Gusztáv Beksics, "I. Ferencz József és kora," in A magyar nemzet története, ed. Sándor Szilágyi, vol. 10, A modern Magyarország (1848-1896) (Budapest, 1898), 395-834.

${ }^{48}$ Gusztáv Beksics, Mátyás király birodalma és Magyarország jövője (Budapest, 1905).

${ }^{49}$ Ibid., 237.

${ }^{50}$ József Tabódy, Ausztria hivatása és egy Magyar-birodalom lehetősége (Pest, 1861); Károly Szini, Magyar birodalom: Javaslat a magyar kérdés megoldására (Pest, 1866).

${ }^{51}$ János Vajda, Magyar birodalmi politika (Budapest, 1881).

${ }^{52}$ Mercator [pseud.], A nemzetiségi kérdés és a magyar birodalmi eszme (Budapest, 1908), also in German: Die Nationalitätenfrage und die ungarische Reichsidee (Budapest, 1908).
} 
a radical reform for all of the Habsburg lands. However, representatives of this thought lacked political leverage and were disconnected, hence I would hesitate to call their scattered initiatives a discourse.

While these currents of imperial discourse were limited to the territory under the scepter of the House of Habsburg, another meaning of empire, as essentially equivalent to the great powers, gained currency as well. A Hungarian empire expanding to Southeast Europe became a frequently discussed topic in Hungarian political discourse in the late nineteenth century. This genuinely imperialistic discourse was justified by evoking the memory of medieval Hungary's foreign policy: the House of Árpád, in particular under the rule of Béla III (r. 1172-96); the House of Anjou, especially Louis I (r. 134282); and Mathias Corvinus had all pursued an expansive foreign policy that resulted in (largely temporary) Hungarian suzerainty over several East and Southeast European polities. ${ }^{53}$

The concept of a Hungarian empire centered on medieval suzerainty started well before the Vormärz and not even in Hungary but in the continental center of the late Enlightenment, Göttingen. The pioneer of East and North European history, August Ludwig Schlözer, together with eminent scholars Johann Christian Gatterer, Christian Gottlieb Heyne, and Arnold Heeren launched the book series Allgemeine Weltgeschichte, modeled on the London series Universal History from the Earliest Account of Time to the Present. Allgemeine Weltgeschichte was based on a geographical logic, hence its volumes discussed individual states rather than epochs in world history. The northern and eastern parts of Europe were assigned to Ludewig Albrecht Gebhardi, a scholar trained in Göttingen and working as a court historian in Hannover. ${ }^{54}$ In his History of the Realm of the Hungarians and the Lands Associated with Them, Gebhardi discussed Hungary in an extended way. In the introduction, Gebhardi explained that Hungarians had once been great warriors and subjugated several peoples and polities around them; accordingly, the work discussed first Hungary proper, to be followed by Transylvania, Galicia, Dalmatia, Croatia and Slavonia, Serbia, Bosnia, Dubrovnik, Bulgaria, Wallachia, and Moldavia. ${ }^{55}$ A few years later, the same concept was employed by Johann Christian Engel, a Hungarian-born and also Göttingen-educated historian and clerk in the Hungarian royal administration. His History of the Hungarian Realm and Its Adjoining Countries (1797-1804) was practically divided into the same sections as that of Gebhardi, though it superseded it in originality. ${ }^{56}$ Both Gebhardi and Engel used the German term Reich as a synonym for Königreich in reference to Hungary (the Hungarian Diet was also called Reichstag in German). Reich here thus translates into English best as "realm" and not "empire," and, similarly, the Hungarian translation of Gebhardi's work was also published as the "History of Hungary" (Magyar ország históriája, translated by István Kultsár in 1803). ${ }^{57}$

As the late Enlightenment slowly turned into romanticism, Hungarian historians started to craft their scholarship in Magyar and simultaneously discovered the expansive foreign policy of medieval Hungary. ${ }^{58}$ As discussed in the preceding text, the widest definition of Hungary in the taxonomy of Fényes also rested on the memory of the medieval Hungarian rule over some "adjoining" provinces. Fed by the "memory" of the medieval Hungarian rule in Southeast Europe, several liberal politicians (the young polymath and later director of the National Museum Ferenc Pulszky, the veteran liberal Count Károly Zay, and the Transylvanian liberal Dénes Kemény) initiated a cautious Hungarian engagement in Southeast Europe during the 1840s. ${ }^{59}$ Nonetheless, while these initiatives were

\footnotetext{
${ }^{53}$ Pál Engel, The Realm of St Stephen: A History of Medieval Hungary, 895-1526, trans. Tamás Pálosfalvi (London, 2001), 5254, 134-36, 161-69, 302-9.

${ }^{54}$ Monika Baár, “From General History to National History: The Transformations of William Guthrie’s and John Gray’s A General History of the World (1736-1765) in Continental Europe," in Cultural Transfer through Translation: The Circulation of Enlightened Thought in Europe by Means of Translation, ed. Stefanie Stockhorst (Amsterdam, 2010), 63-75.

${ }^{55}$ Ludewig Albrecht Gebhardi, Geschichte des Reichs Hungarn und der damit verbundenen Staaten, 4 vols. (Leipzig, 1778-82), 1:3.

${ }^{56}$ Johann Christian von Engel, Geschichte des Ungrischen Reiches und seine Nebenländer, 4 vols. (Halle, 1797).

${ }^{57}$ Baár, "From General History to National History," 76-79.

${ }^{58}$ The veteran historian György Fejér, for instance, published three volumes containing sources of the medieval Hungarian rule over Dalmatia, Galicia, Bosnia, Serbia, Bulgaria, Wallachia, Moldavia, and Bessarabia: Dalmatiae cum regno Hungariae nexus (Buda, 1834); Galiciae ac Lodomeriae cum regno Hungariae nexus. Codex diplomaticus Hungariae vol. IX, no. 4 (Buda, 1834); Commentarii historici de Bosniae, Serviae ac Bulgariae tum Valachiae, Moldaviae ac Bessarabiae, cum regno Hungariae nexu (Buda, 1837).

${ }^{59}$ Romsics, “A magyar birodalmi gondolat," 127-29.
} 
obviously imperialistic, they did not yet apply the term "empire"; birodalom still represented the vision of the composite Hungarian nation-state.

The chaotic spring of 1848 brought about considerable changes to the geopolitics of Central Europe. The elections to the Frankfurt Parliament in April and its actual convention in May made the creation of a united Germany likely, leaving the fate of the Habsburg lands outside of the German Confederation (Hungary, Croatia, Slavonia, Dalmatia, and Galicia) open. According to the British traveler-diplomat Joseph Andrew Blackwell, Lajos Batthyány, prime minister of the lawful revolution, flirted in April 1848 with the idea of creating a "great empire" that would even attract Moldavia and Wallachia. ${ }^{60}$ Blackwell's commentary, however, may be distorted because the text was translated twice (from French through English to Hungarian); moreover, outside of the rather unclear wording of Blackwell, other sources do not document any similar initiative. Even if Batthyány did mean the integration of the "leftover" Habsburg lands into a polity headed by a Hungarian empire, the later events of 1848, and in particular the decision of the Habsburg court to prefer the undisturbed rule over their provinces to the western provinces joining united Germany, obscured any dreams of a Hungarian empire beyond its borders.

From 1849 to around the 1880s, the idea of Hungarian expansion to Southeast Europe practically vanished from Hungarian public discourse. ${ }^{61}$ During neoabsolutism, a Hungarian expansion to Southeast Europe was a bizarre idea, and in the fluid 1860s and 1870s domestic issues dominated the public discourse. Even in 1878 the Hungarian public vigorously opposed any Austro-Hungarian engagement in Bosnia-Herzegovina, and the consent of the Hungarian government to the military action was heavily criticized. ${ }^{62}$

The occupation of Bosnia-Herzegovina meant a decisive turn for the Habsburg monarchy, and especially for Hungary. Hungarians played a crucial role in creating and maintaining Habsburg rule over this province: Benjamin Kállay and István Burián as k. u. k. ministers of finance were ex officio governors of Bosnia-Herzegovina; they were assisted by Lajos Thallóczy, a historian specializing in Southeast European history and a high-ranking clerk in the imperial administration in Vienna. These clerks in the imperial bureaucracy believed that the interests of Austria and Hungary coincided in an imperialistic policy toward Southeast Europe; hence an expansion, whether formal or informal, would benefit both parts of the Habsburg Empire. ${ }^{63}$ By the 1890 s, several lobby groups (including historians, geographers, economists and financiers, journalists, and politicians) that promoted a Hungarian economic and cultural expansion-that is, an informal empire-in the Balkans crystallized. ${ }^{64}$ On the eve of World War I, the scope of Hungarian cultural imperialism extended to the Ottoman Empire and even beyond to several regions in Asia, justified by the controversial linguistic thesis that Magyar, Turkic, and several other Asian languages formed the so-called Turanian language group. ${ }^{65}$ These blurred, culture-based initiatives were replaced by plans for a formalized Hungarian Empire in the Balkans that mushroomed during the war when the Central Powers seemed to triumph

\footnotetext{
${ }^{60}$ Éva Haraszti-Taylor, Joseph Andrew Blackwell magyarországi küldetései 1843-1851 (Budapest, 1989), 18-21; cf. Domokos Kosáry, Ungarn und die internationale Politik 1848-1849, trans. Andreas Oplatka (Vienna, 2017), ch. 4.

${ }^{61}$ Two exceptions may be recalled. In a critical essay in 1851, Zsigmond Kemény, disappointed by the failure of the revolution, argued for the harmonization of the imperial and Hungarian interests. He proposed an extensive imperial foreign policy, Hungary playing a significant role in Southeast Europe; see his Még egy szó a forradalom után (Pest, 1851). In 1862, the exiled Lajos Kossuth proposed the creation of a Danubian Confederation, comprising Hungary, Croatia, Serbia, and Romania and resting on the principle of equality. The proposal earned bitter criticism in Hungary. Nonetheless, none of them argued for a Hungarian empire: Kemény advocated a Habsburg imperial framework, while Kossuth proposed the alliance of equal states.

${ }^{62}$ Imre Ress, “'Der Türke ist ein Freund, [...] wird nicht angefochten': Die Haltung Ungarns zu Bosnien-Herzegowina bis zur Ära Kallay," in Bosnien-Herzegowina und Österreich-Ungarn, 1878-1918: Annäherungen an eine Kolonie, ed. Clemens Ruthner and Tamara Scheer (Tübingen, 2018), 99-119.

${ }^{63}$ Robin Okey, "A Trio of Hungarian Balkanists: Béni Kállay, István Burián and Lajos Thallóczy in the Age of High Nationalism," The Slavonic and East European Review 80, no. 2 (2002): 234-66.

${ }^{64}$ Gábor Demeter, A modernizációtól az expanziós törekvésekig, a liberalizmustól a turanizmusig: A balkáni behatolás gazdasági és ideológiai alapjai (Budapest, 2018).

${ }^{65}$ Joseph A. Kessler, “Turanism and Pan-Turanism in Hungary, 1890-1945” (PhD diss., University of California, 1967); Balázs Ablonczy, Keletre, magyar! A magyar turanizmus története (Budapest, 2016).
} 
in Southeast Europe. Indeed, dreams of a Hungarian great power did not cease in 1918, though in the interwar period only radical and marginal groups entertained such ideas. ${ }^{66}$

Among the arguably cacophonic chorus of Hungarian imperialists, historians and journalists were the most determined to apply the term "empire." In his well-read magnum opus, characteristically entitled The History of the Hungarian Empire Based on Sources, Ignác Acsády appreciated the expansive foreign policy of Ladislaus I (king of Hungary from 1077 and Croatia from 1091 to 1095) who

pursued not only a national but a full-fledged imperial policy. He turned the hitherto little Hungarian state, the continental and fluvial Hungary into a maritime state. He expanded its borders to the Black Sea, the Adriatic Sea, and the Mediterranean, around whose shores the most important events of the civilized world had taken place not only during the antiquity but also in the $11^{\text {th }}$ century and later. By that, he considerably changed the international status of Hungary and her role among the European states. During a single century, the Hungarian Empire elevated onto the rank of a Great Power. ${ }^{67}$

The successor of Ladislaus, King Coloman (ruled in Hungary from 1095, in Croatia from 1102 to 1116), features in a lengthy study by Henrik Marczali, one of the best historians of the age: "During and because of his rule, the Hungarian national state extended into a Hungarian empire subjugating and uniting several nations and longing for goals of a Great Power." ${ }^{\text {"68 }}$ King Béla III attracted the most interest from Thallóczy who emerged as a key figure in understanding how the medieval Hungarian kings brought Serbia, Bosnia, Bulgaria, and Dalmatia into their orbit. In a work typical of Thallóczy, Béla III and the Hungarian Empire, the historian introduces Béla III as a wise statesman of European importance whose cautious but prudent foreign policy yielded in the restoration of control over Dalmatia and Bosnia and increase of influence in Serbia and Bulgaria and put Hungary on par with the Holy Roman and Byzantine empires. ${ }^{69}$

Among the journalists who used the term "Hungarian Empire" in an imperialistic sense, the most influential was the conservative media mogul Jenő Rákosi. He advocated his vision of a Hungarian empire in his well-read daily paper Budapesti Hírlap. The imperial vision of Rákosi largely resembled that of Beksics, his close associate: Rákosi imagined the Hungarian Empire as a strong state with a robust and monolingual population. ${ }^{70}$ Unlike Beksics, however, Rákosi put greater emphasis on the importance of an expansive foreign policy and dreamed of a Habsburg monarchy centered on a strong Hungary whose tasks included an imperialist policy in Southeast European matters. ${ }^{71}$ In an important semantic shift, Rákosi preferred the term for imperialism that clearly associates with a great power, unlike the term "birodalom" that could be used in the more neutral meaning of realm-that is, in the sense of a composite nation-state without any implications in foreign policy. Another remarkable representative of the imperialist usage of magyar birodalom was the astronomer, journalist, and politician Pál Hoitsy, who believed that within a few decades Hungary would achieve the status of a great power and make Southeast Europe its backyard; as a sign of the Hungarian influence in the Balkans, the educated middle class of Sofia, according to Hoitsy, would thus learn Magyar as the language of Western civilization. ${ }^{72}$

\section{Conclusion: Empires in the Habsburg Monarchy}

As Rákosi best demonstrates, the ideal types of the usage of the term "Hungarian Empire" rarely appeared in a pure form. Rather, they were interwoven, and the several meanings of empire mutually

\footnotetext{
${ }^{66}$ Romsics, “A magyar birodalmi gondolat," $144-58$.

${ }^{67}$ Ignác Acsády, A magyar birodalom története a kútfök alapján a müvelt közönség számára, 2 vols. (Budapest, 1903), 1:151-52.

${ }^{68}$ Henrik Marczali, Az Árpádok és Dalmáczia, Értekezések a történeti tudomány köréből, vol. 17, no. 5 (Budapest, 1908 ), 77.

${ }^{69}$ Lajos Thallóczy, "III. Béla és a magyar birodalom," in III. Béla magyar király emlékezete, ed. Gyula Forster (Budapest, 1900), 57-97.

${ }^{70}$ Ildikó Nagy, “Rákosi Jenő és a harmincmilliós magyar imperium," in Híd a századok felett: Tanulmányok Katus László 70. Születésnapjára, ed. Péter Hanák and Mariann Nagy (Pécs, 1997), 295-307.

71"Magyar imperiálizmus," Budapesti Hírlap, 27 Mar. 1901.

${ }^{72}$ Pál Hoitsy, Nagy-Magyarország: A magyar történet jövő századai (Budapest, 1902).
} 
reinforced each other: the Hungarian Empire as a sovereign and composite state often conflated with the vision of a great power pursuing an expansive imperialistic policy. Typical in this regard was the work of the Piarist cleric Ede Ivánfi, who combined the two major understandings of a Hungarian empire: in his The Coat of Arms and Colors of the Hungarian Empire he provided lengthy descriptions of the coat of arms of the present "adjoining lands" of Hungary (Slavonia, Croatia, Transylvania, and Dalmatia, though the latter, in fact, did not "adjoin" Hungary) and the provinces abroad once subordinated to Hungary (Bosnia, Serbia, Galicia, Wallachia, Moldavia, and Bulgaria). ${ }^{73}$ This confluence explains the inconsistent terminology of Acsády, Marczali, and Thallóczy: all of them called the early Hungarian state "the Empire of St. Stephen" (in the sense that it was sovereign but not centralized) but credited later monarchs with the achievement of turning this polity into a genuine imperialistic empire. Rezső Havass demanded not only the transfer of Dalmatia from Cisleithania to the "Hungarian Empire" but also became one of the most vocal advocates of a Hungarian economic expansion to Southeast Europe. ${ }^{74}$ Even more instructive is the journalism of Rákosi, who combined all possible meanings of a Hungarian empire: in his vision, once Hungary turned into a strong, monolingual nation-state, it would automatically attract the center of the Habsburg monarchy, which would empower Hungary with even more leverage in the policies of the Habsburg Empire and, at the same time, the Magyar nation would expand its power beyond its national borders into Southeast Europe.

The twofold but conflated understandings of an empire beyond (or underneath) the AustroHungarian level was certainly a unique phenomenon and can be explained by Hungary's special status as a semisovereign polity whose political elite enjoyed an extraordinary influence in the matters of the Dual Monarchy. The contours of the different meanings of a Hungarian empire are better understood when shortly confronted with the contemporary political discourse in Croatia and in the Czech lands.

Because the Croatian lands did not belong to the Holy Roman Empire, their "imperial history" in legal terms started in 1804, similar to Hungary. The historic rights of the lands of the Croatian Crown became a salient question in politics and legal and historical scholarship. ${ }^{75}$ Croatian legal scholars left little doubt that Croatia "existed and should still exist, as an independent, autonomous state" because its state rights were straightforward. ${ }^{76}$ The Croatian statehood was also to include Slavonia (which, in fact, it did after 1868) and Dalmatia (this demand remained a dead letter), fairly similar to Hungary, which was to incorporate Transylvania and the other "adjoining" provinces. ${ }^{77}$ Difference emerged in the terminology only: while in Hungary the term "Hungarian Empire" stood for the unity of the regna of the Crown of St. Stephen, in Croatian discourse the term "Triune Kingdom" (Trojedna kraljevina) gained currency, "empire" being reserved for Austria and the House of Habsburg.

In contrast to Hungary and Croatia, empire was an everyday reality in the lands of the Czech Crown. The Czech lands joined the Holy Roman Empire in the eleventh century and the king of Bohemia had been an elector of the Holy Roman Empire since the first documentary evidence of the electoral college in the twelfth century. Several Holy Roman emperors, such as Charles IV and Rudolf II, chose Prague as their residence. The transition from the Holy Roman to the Austrian Empire had thus even less impact on the Czech lands than in Hungary and Croatia. Empire and kingdom existed in relative harmony in Bohemia, though the Bohemian estates managed to make

\footnotetext{
${ }^{73}$ Ede Ivánfi, A magyar birodalom címerei és színei (Budapest, 1873).

${ }^{74}$ Havass, Magyar imperiálizmus.

${ }^{75}$ Wolfgang Kessler, “Vom Recht der Stände zum 'Kroatischen Staatsrecht': Zum Historischen Recht in der Politischen Kultur des 19. Jahrhunderts in Kroatien," in Reiche und Territorien in Ostmitteleuropa: Historische Beziehungen und Politische Herrschaftslegitimation, ed. Dietmar Willoweit and Hans Lemberg (Munich, 2006), 379-404.

${ }^{76}$ Ivan Andrović, Das Verhältnis zwischen Kroatien und Ungarn (Vienna, 1904), 20, as cited in Natasha Wheatley, "Law, Time, and Sovereignty in Central Europe: Imperial Constitutions, Historical Rights, and the Afterlives of Empire" (PhD diss., Columbia University, 2016), 60-61.

${ }^{77}$ Beyond the three historical provinces, several Croatian nationalist leaders advocated the transfer of Istria (part of the Cisleithanian crownland Austrian Littoral) and Bosnia-Herzegovina to Croatia, to "adjust" the political borders in accordance with the imagined Croatian ethnic territory. While the Croatian approach to Bosnia was clearly colonial, the term "empire" was not used for the potential extension of the Triune Kingdom. Bojan Baskar, "Small National Ethnologies and Supranational Empires: The Case of the Habsburg Monarchy," in Everyday Culture in Europe: Approaches and Methodologies, ed. Máiréad Nic Craith, Ulrich Kockel, and Reinhard Johler (Aldershot, 2008), 70-73.
} 
Ferdinand issue his decrees as king (and, therefore, used the number V, similar to Hungary) and the lack of a Bohemian royal coronation of Francis Joseph frustrated the Czech public considerably. ${ }^{78}$ Similar to Hungary and Croatia, the emerging Czech national movement heavily deployed a historicallegal argumentation that claimed the unity and sovereignty of the three lands of the Crown of St. Wenceslas: Bohemia, Moravia, and Silesia. An administrative integration of these three lands, however, was not foreseen by the Czech political mainstream. On the contrary, maintaining the historical provinces was a safeguard against German attempts at creating a Bohemian German crownland. A single term referring to the unity of the Czech lands as apt as the "Hungarian Empire" or the "Triune Kingdom," however, did not emerge (and the terms "Bohemian" and "Czech" remained blurred); instead, one talked about the "Lands of the Czech Crown" or simply "Czech Lands" or, relatively rarely before 1918, about Czechoslovakia. ${ }^{79}$ Empire was reserved for the House of Habsburg and either Cisleithania or the entirety of Austria-Hungary.

How many empires, then, existed within the Habsburg Empire of the long nineteenth century? The answer to this question, of course, is contingent on the definition of empire. This article deliberately avoided engaging in the debate over what constitutes an empire, and hence with the question of whether Dualist Hungary "was more of an imperial structure than it is customarily acknowledged to have been," as Gábor Egry has recently claimed. ${ }^{80}$ What is sure, however, is that empire was imagined in Dualist Hungary in a characteristically different way than in the rest of the Habsburg monarchy. The first imperial imagination emanated from a political program of state rights against a centralizing imperial center and turned into a nationalist paradigm of integrating the scattered parts of the body of the nation. In essence, the Hungarian agenda did not differ from its Croatian and Czech counterparts: in all three cases, advocates of the rights of the estates-and later on, nationalist leaders- believed that (1) indivisible bonds connected the regna of the respective crowns and (2) the regna together held all the characteristics of sovereign statehood. ${ }^{81}$ Compared to the Croatian and the Czech counterparts, the Hungarian invention was only terminological. Yet, because "empire" could mean not only a composite state but also a great power, the Hungarian Empire soon took an additional shape as well. The imperialist vision of lands well beyond the national borders was thus a far more genuine concept of empire, though one less realized than the former. A Hungarian great power, whether within, in alliance with, or in contrast to the Habsburg monarchy, did not come into being, but this widely discussed imagination adds a layer to the debate as to what kind of empire the late Habsburg monarchy was.

Acknowledgements. This article was written with the support of the Premium Postdoctoral Fellowship of the Hungarian Academy of Sciences. I am grateful to members of the Department of Modern History, Institute of History, Eötvös Loránd Research Network, and to Gergely Romsics for their commentaries on an earlier version of this article, as well as to the two anonymous reviewers.

Bálint Varga is a research fellow at Eötvös Loránd Research Network, Institute of History, Budapest. His book, The Monumental Nation: Magyar Nationalism and Symbolic Politics in Fin-de-siècle Hungary (2016) received the Richard G. Plaschka Award of the Austrian Academy of Sciences. His current book project explores the reception of globalization in Habsburg Central Europe.

\footnotetext{
${ }^{78}$ Evans, "Communicating the Empire," 131.

${ }^{79}$ Peter Haslinger, Nation und Territorium im tschechischen politischen Diskurs 1880-1938 (Munich, 2010), 67-106.

${ }^{80}$ Gábor Egry, "Regional Elites, Nationalist Politics, Local Accommodations: Center-Periphery Struggles in Late Dualist Hungary," in Österreich-Ungarns imperiale Herausforderungen: Nationalismen und Rivalitäten im Habsburgerreich um 1900, ed. Bernhard Bachinger, Wolfram Dornik, and Stephan Lehnstaedt (Göttingen, 2020), 334.

${ }^{81}$ Cf. Wheatley, "Law, Time, and Sovereignty in Central Europe."
}

Cite this article: Varga B (2021). The Two Faces of the Hungarian Empire. Austrian History Yearbook 52, 118-130. https:// doi.org/10.1017/S0067237820000545 